MATJAŽ KNEZ, M.Sc.

E-mail: matjaz.knez@fl.uni-mb.si

BOJAN ROSI, Ph.D.

E-mail: bojan.rosi@fl.uni-mb.si

University of Maribor, Faculty of Logistics Celje - Krško

Mariborska cesta 7, SI-3000 Celje, Republic of Slovenia

MATJAŽ MULEJ, Ph.D.

E-mail: mulej@uni-mb.si

University of Maribor, School of Economics \& Business

Razlagova ulica 14, SI-2000 Maribor, Republic of Slovenia

MARTIN LIPIČNIK, Ph.D.

E-mail: martin.lipicnik@uni-mb.si

University of Maribor, Faculty of Logistics Celje - Krško

Mariborska cesta 7, SI-3000 Celje, Republic of Slovenia
Transport Logistics

Review

Accepted: Apr. 21, 2009

Approved: May 17, 2009

\title{
COMPETITIVENESS BY REQUISITELY HOLISTIC AND INNOVATIVE LOGISTIC MANAGEMENT
}

\begin{abstract}
In the age of global expansion of business operations and contemporary way of life the material and information flows in and between different companies are growing rapidly; they are thus becoming more and more difficult to manage. Had business functions in companies been dealt with separately until now (purchase, production, finances, sale, etc.), today the emphasis is placed on their integration due to their interdependence. By studying supply chains inside and between business partners, companies can gain competitive advantage and become more adjustable, taking the increasingly changing market circumstances into account. This enables them to meet consumers' demands and expectations requisitely holistically. Taking all the crucial activities into account, the logistics management plays a key role in the companies facing the challenges of the new millennium. Based on the numerous megatrends, which influence each and every business entity, this article aims to explain the increasing strategic importance of logistics management. The latter may not be dealt with one-sidedly as a cost; moreover, the key aspects such as competitiveness as well as longterm existence of a company must also be considered. Innovation and systemic thinking in it and about it are needed.
\end{abstract}

\section{KEY WORDS}

logistics management, logistics strategy, supply chains, megatrends, innovation, systemic thinking

\section{INTRODUCTION}

Based on decades of experience in logistics, innovation, and systemic thinking of most co-authors we detected that the current prevailing understanding of logistics is not requisitely holistic, but one-sided; it still matches predominantly the market perception from the times of local market and production for known consumers who tend also to be neighbours. Thus, we feel the need to contribute to a more/requisitely holistic perception of logistics. Our thesis reads: the key mechanisms for maintaining competitive advantage today include a requisitely holistic approach to logistics, standardization, or introduction of adequate standards, high level of responsiveness, compatibility with other elements of organizational structure and business environments in general. We will apply the Dialectical Systems Theory (Mulej, 2008, and earlier, since 1974) with its law of requisite holism in order not to make essential oversights/one-sidedness.

\section{THE MARKET TRENDS AND LOGISTICS}

Logistics has always been present in exchange and production of goods. However, its importance has grown during the current intense globalization process. Companies have started to realise the importance of logistics' organization and hence competitive advantage. Today, companies are striving to meet the needs of most demanding customers ${ }^{1}$ expecting an ever better customer service. Therefore, a company may quickly lose its market share, if it cannot maintain the desired level of customer service.

Logistics is a practice-oriented and solution-based discipline, and has developed under strong influence from physical sciences by making non-living phenomena its study objects. The predominant objects of study relate to tangible artefacts [10], but to a smaller extent human intervention or influence. Logistics has 
grown out of physical distribution, transportation and inventory management, where physical objects constitute the structure encompassing an efficient and effective flow. Key performance objectives also strongly indicate the physical dimension, and are methodologically shaped by operations research: truck-loads, ontime in-full deliveries, inventory turnover (related to expire date and working capital), and out-of-stock (OOS) situations. Logistics has welcomed the metaphor of value chain and supply chain that essentially depict a sequence of inter-related activities and structures that share the image of an assembly line. By such a mechanic and deterministic view, it almost becomes self-evident that causality - the cause-effect relationship between various stages in the material flow - becomes the predominant scientific explanation.

According to New and Payne [19] the dominant causal models in logistics focus on the consequences of logistic activities in terms of performance. Logistic activities are assumed to be something "designable" explained as a result of deliberate choice and expected better performance. This design orientation has produced insights with clear managerial relevance. As implied later, however, the consequences are a myopic view on what factors are relevant in order to understand the logistic performance.
The trend of logistics development mainly depends on globalization of the world economy, which has facilitated a number of factors that influence production growth, commoditisation of products, and differentiation of consumer needs. Fierce competition among companies, shorter product lifecycles, and recent crisis-related events call for adjustment of all the supply chain participants. Here, logistics management will play an enormous role, as it will influence either the success of businesses or their failure. Therefore, logistic costs ${ }^{2}$ will also play a decisive role in business competitiveness $^{3}$ in the global market, and belong to advantages that distinguish the given organization from other suppliers in the market.

On those terms, logistics must face today the megatrends in the global market. This requires avoidance of one-sidedness and routine-loving business, while consideration of requisite holism of approach and innovation are unavoidable in the management of logistics.

\section{DEPENDENCE OF OPTIMAL LOGISTICS ON REQUISITE HOLISM AND INNOVATION}

In order to manage our knowledge of logistics, we must also take into consideration the contemporary

Table 1 - Market development and the needs for innovation and systemic thinking in the contemporary phase of social-economic development

\begin{tabular}{|c|c|c|c|}
\hline $\begin{array}{l}\text { Type of Viewpoints } \\
\text { market }\end{array}$ & $\begin{array}{l}\text { Basic relation/s be- } \\
\text { tween production } \\
\text { and consumption }\end{array}$ & $\begin{array}{c}\text { Impact of humans on natural } \\
\text { environment } \\
\text { (exposing human } \\
\text { one-sidedness) } \\
\end{array}$ & $\begin{array}{l}\text { Humankind's interdependence } \\
\text { with natural environment } \\
\text { (requiring more holism) }\end{array}$ \\
\hline $\begin{array}{l}\text { Oldest: } \\
\text { RANDOM MARKET }\end{array}$ & $\begin{array}{l}\text { Producers' own con- } \\
\text { sumption and oc- } \\
\text { casional exchange of } \\
\text { random surpluses }\end{array}$ & $\begin{array}{l}\text { Minimal impact, growing as } \\
\text { humankind grows in number } \\
\text { and needs / requirements }\end{array}$ & $\begin{array}{l}\text { Intuitive human consideration of } \\
\text { nature based on experience in } \\
\text { agriculture, gathering, hunting, } \\
\text { wood cutting, fishing and mining }\end{array}$ \\
\hline $\begin{array}{l}\text { Exceptional today: } \\
\text { SELLERS' / PRODUC- } \\
\text { ERS' PREVAILING } \\
\text { POWER = PRODUC- } \\
\text { ERS' MARKET }\end{array}$ & $\begin{array}{l}\text { Growing production for } \\
\text { poorly considered, known/ } \\
\text { unknown, custom- } \\
\text { ers, who lack impact } \\
\text { over suppliers (supply } \\
\text { smaller than demand) }\end{array}$ & $\begin{array}{l}\text { Specialization and narrow } \\
\text { thinking grow and so does } \\
\text { the humans' detrimental } \\
\text { impact on nature (especially } \\
\text { by industrialised production) }\end{array}$ & $\begin{array}{l}\text { Nature is subordinated to } \\
\text { profit, jobs depend less on nature, } \\
\text { more on growing urbanisation } \\
\text { and manufacturing as well as } \\
\text { industrialised agriculture }\end{array}$ \\
\hline $\begin{array}{l}\text { Neoliberal un- } \\
\text { real model: } \\
\text { BUYERS' / CUSTOM- } \\
\text { ERS' PREVAILING } \\
\text { POWER = BUY- } \\
\text { ERS' MARKET }\end{array}$ & $\begin{array}{l}\text { Growing impact of custom- } \\
\text { ers requiring satisfaction } \\
\text { / total quality of prod- } \\
\text { ucts and services, and } \\
\text { conditions of life (supply } \\
\text { bigger than demand) }\end{array}$ & $\begin{array}{l}\text { Specialisation and its bad } \\
\text { one-sided impact over } \\
\text { nature keep growing, so } \\
\text { does biased application of } \\
\text { science, causing need for } \\
\text { inter-disciplinary cooperation }\end{array}$ & $\begin{array}{l}\text { Nature is still subordinated to } \\
\text { profit, but nature is thought of } \\
\text { more due to cost, caused by } \\
\text { backslash of oversights caused } \\
\text { by one-sided acts for profit; } \\
\text { inter-disciplinary insight grows }\end{array}$ \\
\hline $\begin{array}{l}\text { Contemporary: } \\
\text { STATE / GOVERN- } \\
\text { MENT SUPPORTED } \\
\text { BUYERS' MARKET }\end{array}$ & $\begin{array}{l}\text { Increasingly organised } \\
\text { / legalised impact of } \\
\text { customers demanding } \\
\text { total quality of products, } \\
\text { services and conditions } \\
\text { of life (supply much } \\
\text { bigger than demand) }\end{array}$ & $\begin{array}{l}\text { Growing awareness about } \\
\text { the terrible impact of human- } \\
\text { kind's one-sided impact over } \\
\text { nature \& its dramatic conse- } \\
\text { quences for humans' survival }\end{array}$ & $\begin{array}{l}\text { Same as before, but world-wide of- } \\
\text { ficial documents and actions urge } \\
\text { governments and businesses as } \\
\text { well as humans to be more holis- } \\
\text { tic; so does a part of market (e.g. } \\
\text { by requiring social responsibility) }\end{array}$ \\
\hline
\end{tabular}

Source: (Mulej at al., 2008; renewed) 
Table 2 - From supplying to sustainable and socially responsible company

- growth of need and the choice of topics on innovation

\begin{tabular}{||l|l|l|l||}
\hline Decade & \multicolumn{1}{|c|}{ Market \& social requirements } & \multicolumn{1}{|c||}{ Enterprise's ways to meet requirements } & \multicolumn{1}{|c||}{ Type of enterprise } \\
\hline \hline $1945-$ & $\begin{array}{l}\text { Covering of post-war conditions } \\
\text { of scarcity, rebuilding, etc. }\end{array}$ & $\begin{array}{l}\text { Supply anything; supply does } \\
\text { not yet exceed demand }\end{array}$ & $\begin{array}{l}\text { Supplying } \\
\text { Enterprise }\end{array}$ \\
\hline $1960-$ & $\begin{array}{l}\text { Suitable price (as judged } \\
\text { by customers) }\end{array}$ & Internal efficiency, i.e. cost management & $\begin{array}{l}\text { Efficient } \\
\text { Enterprise }\end{array}$ \\
\hline $1970-$ & $\begin{array}{l}\text { The same as earlier } X^{4} \text { qual- } \\
\text { ity (as judged by customers) }\end{array}$ & $\begin{array}{l}\text { Efficiency X technical \& commer- } \\
\text { cial quality management }\end{array}$ & $\begin{array}{l}\text { Quality } \\
\text { Enterprise }\end{array}$ \\
\hline $1980-$ & $\begin{array}{l}\text { The same as earlier X range } \\
\text { (as judged by customers) }\end{array}$ & The same as earlier X flexibility management & $\begin{array}{l}\text { Flexible } \\
\text { Enterprise }\end{array}$ \\
\hline $1990-$ & $\begin{array}{l}\text { The same as earlier X unique- } \\
\text { ness (as judged by customers) }\end{array}$ & $\begin{array}{l}\text { The same as earlier X innova- } \\
\text { tiveness management }\end{array}$ & $\begin{array}{l}\text { Innovative } \\
\text { Enterprise }\end{array}$ \\
\hline $2000-$ & $\begin{array}{l}\text { The same as earlier X contribu- } \\
\text { tion to sustainable development } \\
\text { (SD) (as judged by customers) }\end{array}$ & The same as earlier X SD & $\begin{array}{l}\text { Sustainable } \\
\text { Enterprise }\end{array}$ \\
\hline $2010-$ & $\begin{array}{l}\text { The same as earlier } X \text { social respon- } \\
\text { sibility (as judged by customers) }\end{array}$ & $\begin{array}{l}\text { The same as earlier X honesty reaching } \\
\text { requisite holism and wholeness beyond } \\
\text { legal demands, i.e. social responsibility }\end{array}$ & $\begin{array}{l}\text { Socially responsible req- } \\
\text { uisitely holistic enterprise }\end{array}$ \\
\hline
\end{tabular}

Source: (Mulej at al., 2008, renewed)

Table 3 - Management of innovation, i.e. invention-innovation-diffusion process, today

\begin{tabular}{|c|c|}
\hline Training & $\begin{array}{l}\text { Professionalism and creativity as well as creative co-operation (will and the abil- } \\
\text { ity and organization for team-work) - seminars, manuals, praxis }\end{array}$ \\
\hline Vision & Sustained competitiveness including social responsibility by requisite holism and innovation \\
\hline Mission & Above-average achievement of systemic quality of the entire business, not only products \\
\hline Policy & $\begin{array}{l}\text { Continuous and goal-oriented search for possible innovations and } \\
\text { their implementation /realisation using a special strategy }{ }^{5}\end{array}$ \\
\hline Strategy & $\begin{array}{l}\text { To assess and develop one's behaviour in line with ISO } 9000 \text { (version from 2000: sys- } \\
\text { temic thinking included) and in line with the European quality/excellence award (new ver- } \\
\text { sion: the basis is learning and innovating) - yet not in a bureaucratic way (which only en- } \\
\text { ables monitoring); support to innovation in strategies of all business functions, too. }\end{array}$ \\
\hline Tactics & $\begin{array}{l}\text { Organized criticism - source for encouragement for creation of ideas, inventions, } \\
\text { suggestions, potential innovations and innovations, partly individually but main- } \\
\text { ly through co-operation with the invention-innovation groups/teams/circles. }\end{array}$ \\
\hline Praxis & $\begin{array}{l}\text { Regular creation of ideas, inventions, suggestions, potential innovations and in- } \\
\text { novations, removal of barriers (if possible) in advance (especially routine- } \\
\text { loving and bureaucratic thinking), and diffusion of innovation. }\end{array}$ \\
\hline $\begin{array}{l}\text { Monitoring and } \\
\text { intervention }\end{array}$ & $\begin{array}{l}\text { MCIQP - management committee for innovation and quality promotion; meets every } 3 \\
\text { or (later) } 6 \text { months: } 1 . \text { Assessment of achievements of all units, } 2 \text {. Variable part of unit } \\
\text { manager's income in relation to that, } 3 \text {. Approval of new innovation objectives. }\end{array}$ \\
\hline Rewarding & $\begin{array}{l}\text { Non-monetary (e.g. information that managers and co-workers view you as creator) and } \\
\text { monetary (for example: one half of income, received from innovation is going to the com- } \\
\text { pany, one half to co-workers, of which } 30 \% \text { go to authors and co-authors, } 10 \% \text { for the } \\
\text { entire unit that came up with the idea, } 10 \% \text { to everyone, including managers) }\end{array}$ \\
\hline
\end{tabular}

Source: (Mulej at al., 2008, renewed)

Table 4 - Equation of conditions for innovation

INNOVATION = (invention $\mathrm{X}$ entrepreneurial spirit and entrepreneurship $\mathrm{X}$ requisite holism $\mathrm{X}$ democratic governance, management and leadership $X$ co-workers $X$ innovation-friendly culture $X$ suppliers $X$ consumers $X$ competitors $X$ social environment $X$ natural environment $X$ occasional events / luck)

Source: (Mulej at al., 2008. renewed) 
reality and knowledge that is summarized in Tables 1-6 [24], [21], [22]:

- Table 1 shows that the circumstances of the statesupported consumer market and its fierce competition must be taken into account, including logistics.

- Table 2 shows that contemporary business participants lack the time to slowly adjust to the new requirements on the market. In logistics, innovation is a rapid process, too.

- Table 3 shows that one constantly has to follow up the new requirements and plan creatively, requisitely holistically and flexibly, in order to be innovative enough.

- Table 4 shows how complex it is to be innovative: all mentioned factors are very important and interdependent.

- Table 5 shows that during the innovation process, one cannot consider just the technological subsystem of inventions, potential inventions, or innovations; there are eight essential contents of them. Amongst them, what matters most is what is the most influential, as it paves the path for other innovations: this is a move from innovation management with the leadership style "I think, and you work and say nothing", into innovation management with the leadership style "all of us think, create, work and hence we innovate together". This is also a shift from the "closed innovation" style, supposing we have all the knowledge and other success factors needed, into "open innovation" style, supposing that for contemporary innovation processes the research, studying, development, and other knowledge comes from everywhere around the world. At the same time, no inventions, suggestions or potential innovations should be stored but marketed at the earliest possible time [3], [4], [15], [16].

The market position of contemporary logistics as briefly summarized in Tables 1-5, is clearly so complex that the requisite holism of its approach to business management and innovation is urgently needed. The European Union's viewpoint is shown in Table 6. The EU explicitly calls for systemic thinking, yet not for any kind of systemic thinking, known today (for overview of them see: [8]). It is important here not to put emphasis on detailed and mathematically-oriented description of the chosen notion from any single viewpoint, but on the Dialectical System Theory [24], and dialectic network thinking [30], [33], [31], [32]. They both aim at integration of experts from various specialist fields. The main points have been briefly summarized in Tables 7-9.

Humans who allow themselves to remain closed inside single selected viewpoints, tend to cause crucial oversights and resulting failures rather than requisite wholeness of their results, because they do not use interdisciplinary creative cooperation leading to requi- site holism of their approach. Some assessments of logistics resulting from requisite holism including cases are briefed in the following part of this contribution.

\section{DISCUSSION}

\subsection{Logistics adds value, not cost}

Logistics is usually referred to as an activity which deals with management of material flows from sources to users, within and between companies and/as customers. Hence, logistics encompasses the physical flow of materials and services and all relevant information and know-how flows from suppliers to producers, retailers, and to the end-customers. Logistics actually supports the physical or material part of the entire lifecycle of a product as well as its reverse path ${ }^{7}$.

As an important part of the value chain, logistics also impacts business processes from suppliers via manufacturers to supermarket shelves or the entire industrial supply chain. That is why the main task of logistics is to provide an optimal flow of materials in the supply chain, in which companies can act as suppliers, manufacturers or distributors. All of them must provide the right goods and services at the right place, at the right time and in the right quantity and quality, at the lowest possible costs and causing minimal environmental damage.

This is why logistics is a crucial supportive process in companies and their supply chains. It encompasses all processes from forecasting, demand, and supply, planning of needs and production to material business, warehousing, material management, packaging, commissioning, distribution, transport, sales and after-sales activities and recycling.

A belief that logistics activities and processes create costs as such is too simplistic. This stems from the belief that warehousing, transport and material management neither incur costs nor add value. If added value is perceived as an increase or improvement of value for users, price, function or usability, then logistics adds value. What is the value of a product in a supplier's warehouse rather than on the production line of a user or on supermarket's shelves? How useful is a tool in a warehouse; and how useful is it when it is used? If logistics is just a cost, then: why do companies keep building modern warehouses for the incoming materials and component parts, and outgoing warehouses for products, transport lines and systems, distribution centres, automatic material management and products, and the like? Probably, due to the fact that material cannot flow without transport, warehousing, and management of material and products.

Though, logistics may become a cost providing for no or poor benefit, if the managerial approach to it is 
M. Knez, B. Rosi, M. Mulej, M. Lipičnik: Competitiveness by Requisitely Holistic and Innovative Logistic Management

Table 5 - Typology of inventions/suggestions, potential innovations, and innovations

\begin{tabular}{||l|c|c|c|c||}
\hline \multicolumn{1}{|c|}{$\begin{array}{c}\text { Three networked criteria of inv., sugges- } \\
\text { tions, pot. innov., and innovations }\end{array}$} & \multicolumn{2}{c|}{$\begin{array}{c}\text { (2) Consequences } \\
\text { of innovations }\end{array}$} & \multicolumn{2}{c||}{$\begin{array}{c}\text { (3) On-job-duty to create inv., sugg., } \\
\text { potent. innovations, and innovations }\end{array}$} \\
\hline \hline $\begin{array}{l}\text { (1) Content of inventions, suggestions, } \\
\text { potential innovations, and innovations }\end{array}$ & 1. Radical & 2. Incremental & 1. Duty exists & 2. No duty \\
\hline 1. Business program items & 1.1. & 1.2. & 1.3. & 1.4. \\
\hline 2. Technology (products, processes...) & 2.1. & 2.2. & 2.3. & 2.4. \\
\hline 3. Organization & 3.1. & 3.2. & 3.3. & 3.4. \\
\hline 4. Managerial style & 4.1. & 4.2. & 4.3. & 4.4. \\
\hline 5. Methods of leading, working and co-working & 5.1. & 5.2. & 5.3. & 5.4. \\
\hline 6. Business style & 6.1. & 6.2. & 6.3. & 6.4. \\
\hline 7. Management process & 7.1. & 7.2. & 7.3. & 7.4. \\
\hline 8. Values, culture, ethics, \& norms & 8.1. & 8.2. & 8.3. & 8.4. \\
\hline
\end{tabular}

Source: (Mulej at al., 2008, renewed)

Table 6 - Systemic thinking about innovation according to EU definition (2000, p. 6).

\begin{tabular}{|c|c|}
\hline 'The Action Plan [First Action Plan for Innovation in Europe, 1996, based on Green Paper on Innovation, \\
1995] was firmly based on the 'systemic' view, in which innovation is seen as arising from complex interac- \\
tions between many individuals, organizations and environmental factors, rather than as a linear trajec- \\
tory from new knowledge to new product. Support for this view has deepened in recent years [7]'. \\
\hline
\end{tabular}

Table 7 - The difference between (1) fictitious, (2) requisite and (3) total holism

\begin{tabular}{|c|c|c|}
\hline \multicolumn{3}{|l|}{$\leftarrow$} \\
\hline $\begin{array}{l}\text { One-sidedness, restricted } \\
\text { to only one aspect - mental } \\
\text { picture, causing fictitious } \\
\text { holism, usual with narrow } \\
\text { specialists with no interdisci- } \\
\text { plinary creative cooperation }\end{array}$ & $\begin{array}{l}\text { Dialectical system (= network), that connects in a synergy } \\
\text { all essential and only essential aspects into a rational } \\
\text { and/or emotional picture about the discussed notion that } \\
\text { matches the requisite holism and hence reduces reduction- } \\
\text { ism to the extent that it enables a real enough cognition } \\
\text { and action, by interdisciplinary creative cooperation. }\end{array}$ & $\begin{array}{l}\text { Total holism with the net- } \\
\text { work of all aspects - men- } \\
\text { tal pictures; it reaches } \\
\text { beyond human capabili- } \\
\text { ties, even by interdisciplin- } \\
\text { ary creative cooperation }\end{array}$ \\
\hline
\end{tabular}

Source: (Mulej at al., 2008, renewed)

Table 8 - Definition of holism according to dialectic system theory
Holism encompasses thinking, decision-making and action that further includes:
(1) the entire whole (systemic),
(2) its single parts (systematic),
(3) relationships (interdependence, dialectics) and
(4) reality (closeness of thinking to reality),
as a system, i.e. network, everything is interwoven, interdependent.

Source: (Mulej at al., 2008)

Table 9 - Systemic thinking - short definition

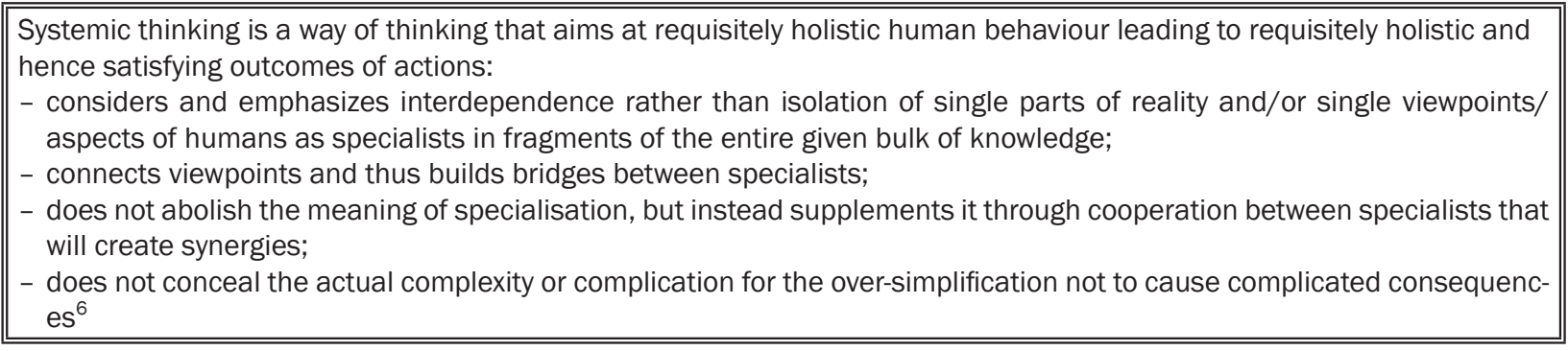

Source: (Mulej at al., 2008, renewed) 
not requisitely holistic and thus does not result in requisitely wholeness of its outcomes. Holism and wholeness depend essentially on the definition of goals of logistics management [24], [22].

\subsection{Goals of logistics management}

Goals reflect, and result from humans' starting points concerning the processes to be managed and mastered. Thus goals depend on five interdependent components of humans' subjective starting points [20]:

- Objective needs, which are expressed e.g., as demand in markets, including the demand for logistic services;

- Objective possibilities, which are expressed e.g. as available sources in nature and markets, including logistic capacities and facilities;

- Subjective knowledge on content, which persons in charge of drafting of, and decisions on, goals definition have and use to answer the question what is the essence of what is dealt with, such as logistics;

- Subjective knowledge as know-how, which the same persons have and use to answer the question "how can we handle it", such as logistics process;

- Subjective values, which the same persons have and use as their more or less emotional background of their actions, such as ambitions concerning logistics.

With the synergy of their three subjective attributes, humans in charge perceive objective need and possibilities and select from them the preferential ones in order to define their goals requisitely holistically.

In the case of logistics management this insight implies several requirements including the consideration of the following experiences:

- Logistics management is an interdisciplinary and universal combination of many activities (from forecasting, demand, supply, demand and production planning to material business, warehousing, handling of goods and services, packaging, commissioning, distribution, transport, sale and after-sale activities, etc.).

- Business logistics is a social process. That is why the content of this universal process follows the social development tendencies. The increasing globalization of markets and greater individualization of needs, ICT, environmentally friendly implementation of logistics services and increased presence of terrorism and crime are the five megatrends [17] that call for the innovation of business focus. Hence, they present a real challenge to logistics management. In the past few years these five megatrends have been shaping business logistics.
- System logistics management will be shaping and integrating goals, decision makers, structure and the company's ability of flexibility depending on the current combination of different megatrends. Taking social megatrends into account can help companies gain competitive advantage by choosing appropriate logistics strategies.

- Fiercer competition in international markets forces companies to be innovative. Companies must thus constantly prove that they are trustworthy and can at the same time expand to new markets. This is only possible if companies are market-oriented. This is also true for all business systems in a company, a part of which is also logistics as an important business function. Market-oriented logistics calls for the following prerequisites:

1. Familiarisation of markets;

2. Implementation of the concept of efficient customer service;

3. Offering the right quantities of goods at reasonable prices at the right place and at the right time;

4. Covering after-sale services.

Logistics systems must thus have the objective to meet customers' needs and contribute to the entire efficiency of the company. In this way, the outcomes of the operation may be assessed. Knowledge what logistics is and/or what its goals are enables companies to determine the operational tasks and organizational mode. The aim of logistics system is to optimally provide production with needed materials and energy and optimally provide users with products in desired quantity, quality and at the right time. The aim is to achieve an optimal level of supply service [27].

This aim is easier to attain, if reality is considered and related actions are based on requisite holism and innovation.

\subsection{Megatrends}

In Chapter 4.2 we briefly discussed the following five contemporary megatrends:

1. Increasing globalisation of markets,

2. Individualisation of customers' wishes,

3. Information computer technology (ICT),

4. Environmentally friendly implementation of logistics services, and

5. Increased presence of terrorism and crime.

Apparently, the financial and general economic crises could and should be added in 2008 and later because these have become social.

Chapter 3 added megatrends of ways of solving the issues of these five megatrends, and the crisis of 2008 and later. 
If we look at the findings summarized above, we can see that the megatrends have two common denominators that have been highlighted in Chapters 3 and 4:

- The need for successful new solutions, i.e. innovations in logistics and elsewhere, as we cannot solve problems by using means which have caused them;

- The need for requisite holism and wholeness in logistics and elsewhere, so that the invention-innovation process can yield innovations instead of failures, which is too often the case. The assessment of innovation projects of big companies has namely concluded that the success rate of these processes is less than 5 per cent [26]. This means that less than one thousandth of ideas is successful. A small number of ideas - inventions become recorded suggestions, small number of suggestions becomes projects and a minority of the projects provides potential innovation. And only a minority of them succeeds in becoming an actual innovation.

The main issue in logistics is requisite holism and innovation of operation and cooperation of experts in the field. How essential it is to consider the natural environment cannot be discussed at this point and is hopefully not needed, as the sources speak for themselves [1], [2], [6], [35]. However, one needs to point out that many sources [23] indicate that the most essential management innovation is the fact that it is holistic and innovative, as well as that it promotes social responsibility [11], [12], [13], [14], [34], [25] and contemporary ethics [28], [29]. The main part of innovations management would be the development of company's competences, to be open to novelties from research institutions and implement them into their praxis [21]. However, this calls for further research that should tackle new kinds of megatrends.

\section{CONCLUSIONS}

The main goal of successful companies is survival and profit by a solid and stable competitive advantage. Changing conditions of production and demands of the changing environment are forcing the companies to adjust to such changes using different combinations of business factors. Logistics management or business function of logistics will play a more and more important role. It is thus a complex "synergetic activity", which encompasses several sub-functions of the economic system, each of which could be dealt with individually. However, it is important that the bundle of connected activities promotes safe, ecological, fast and cheap movement of raw materials, semi-finished products and finished products to final consumers. If the companies can do that then we can talk about an efficient and successful logistics management and hence satisfied customer. To this end, companies must engage in innovations using the requisite holism to attain requisite wholeness of outcomes and therefore to succeed.

Mag. MATJAŽ KNEZ

E-mail: matjaz.knez@fl.uni-mb.si

Dr. BOJAN ROSI

E-mail: bojan.rosi@fl.uni-mb.si

Univerza v Mariboru, Fakulteta za logistiko Celje - Krško

Mariborska cesta 7, 3000 Celje, Republika Slovenija

Dr. MATJAŽ MULEJ

E-mail: mulej@uni-mb.si

Univerza v Mariboru, Ekonomsko-poslovna fakulteta

Razlagova ulica 14, 2000 Maribor, Republika Slovenija

Dr. MARTIN LIPIČNIK

E-mail: martin.lipicnik@uni-mb.si

Univerza v Mariboru, Fakulteta za logistiko Celje - Krško

Mariborska cesta 7, 3000 Celje, Republika Slovenija

\section{POVZETEK}

\section{DO KONKURENČNOSTI S CELOVITIM IN INOVATIVNIM LOGISTIČNIM MANAGEMENTOM}

Doba globalne ekspanzije poslovanja in sodobnega načina življenja povzroča hitro in vedno težje obvladljivo rast blagovnih in informacijskih tokov $v$ podjetjih in med njimi. Če smo nekdaj obravnavali poslovne funkcije $v$ podjetju (nabavo, proizvodnjo, finance, prodajo ...) ločeno, se danes stroka vse bolj posveča njihovemu povezovanju zaradi soodvisnosti. Proučevanje oskrbnih verig v podjetju in med poslovnimi partnerji daje podjetju možnosti, da postane bolj konkurenčno in bolj prilagodljivo, glede na vedno hitrejše spreminjanje tržnih razmer. To pomeni čimbolj celovito zadovoljevanje odjemalčevih zahtev oz. pričakovanj. Pri spletu teh aktivnosti ima ključno vlogo menedžment logistike kot odgovor in strategija podjetij, pripravljenih na izzive 21. stoletja. $V$ članku smo želeli pokazati, kako se na številne t.i. megatrende ${ }^{8}$, ki vedno bolj vplivajo na poslovanje slehernega gospodarskega subjekta, povečuje strateški pomen menedžmenta logistike. Slednje ne smemo enostransko obravnavati kot strošek, ampak celoviteje, tj. kot ključni vir konkurenčnosti in dolgoročnega obstoja podjetja. Pospeševati moramo inoviranje in sistemsko razmišljanje o in $v$ njej.

\section{KLJUČNE BESEDE}

menedžment logistike, logistična strategija, oskrbne verige, megatrendi, inoviranje, sistemsko razmišljanje

\section{REFERENCES}

1. If buyers had been treated as kings in the 1970s, they have become "dictators", today, dictating demands that supply chains must obey, in order to meet their demands and stay competitive. (Table 1)

2. Especially in cases of products and services with small margins they will do so.

3. Competitive advantage results from innovative combination of knowledge, special skills, technology, information and unique business methods that enable the supply of products and services that the buyers appreciate and want to buy [9]. 
4. X denotes interdependence resulting in synergy. No attribute is avoidable any longer for a longer-term success. The original table [37] did not contain X, but + The sign + denotes that interdependencies and resulting synergies are not considered; elements are only summed up in it. Experience shows summation is an oversimplification. The original did not contain the decades of 1950 and 2000 either. NB: SD = sustainable development.

5. This strategy includes:

(1) The three most important business functions marketing, research, development, i.e. marketing (i.e. research and market development and its successful implementation), research (i.e. technical-technological characteristics of products) and development (i.e. implementing research results into production and other business practices). Production still remains very important. However, due to contemporary circumstances it cannot dictate the market, but has to adjust to it.

(2) Leadership style is to think, invent, and work. The old one was "think or work". We all think and work and we are all part of invention-innovationdiffusion processes.

(3) The reaction of employees, who are influenced by the change of style from point (2), is the mass activation of competences and values for the creation of inventions/suggestions, potential innovations and innovations.

6. The need for systemic thinking which uses system theory as its formal, scientific basis is based on the nature of logistics and also works for logistics, as it connects many activities and allows them to make sense in synergy.

7. Reverse logistics deals with the management of waste that occurs in all parts of supply, production and distribution. Material flow has the opposite direction of the previous three parts of logistics. It must follow economic and ecological objectives. The actual tasks of reverse logistics are: planning and dismantling of old equipment from buyers and manufacturers, waste collecting, sorting and separation, intermediate warehousing, manipulations and transport of waste, recycling (reuse of materials), collecting, deposition and discharging of waste. Based on the shorter life cycle of products and ecological regulations and standards, the importance of reverse logistics is gaining importance [35]. The reverse logistics also requires requisitely holistic management, but we will not tackle its specifics in this contribution.

8. A megatrend is a strong and clear direction of a longterm general development process.

\section{LITERATURE}

[1] Božičnik, S.: Dialektično sistemski model inoviranja krmiljenja sonaravnega razvoja cestnega prometa. Univerza v Mariboru, Ekonomsko-poslovna fakulteta, Maribor, 2007

[2] Božičnik et al.: Sustainable future (2), requisite holism, and social responsibility: (against the current abuse of free market society), Korte : SEM, Institute for Climate Change, 2008
[3] Chesbrough, H. W.: Open Innovation. The New Imperative for Creating and Profiting from Technology. Boston, Ma. Harvard Business School Press, 2003

[4] Chesbrough, H., Vanhaverbeke, W., West, J.: Open Innovation: Researching a New Paradigm. Oxford, New York: Oxford University Press Inc., 2006

[5] Ečimovič, T., Mulej, M., Mayur, R.: Systems Thinking and Climate Change System (Against a Big "Tragedy of the Commons" of All of Us). SEM Institute for Climate Change, Korte. http://www.institut-climatechange.si, 2002

[6] Ecimovic, T., Esposito, M., Flint, W., Haw, R. B., Mulej, M., Shankaranarayana, M. A., Wilderer, P. A., Williams, L.: Sustainable (Development) Future of Mankind. Korte: SEM Institute for Climate Change, http:// www.institut-climatechange.si, 2007

[7] EU (2000): Communication from the Commission to the Council and the European Parliament: Innovation in a knowledge-driven economy. Commission of the European Communities, Brussels, xxx $\operatorname{COM}(2000) 567$ final.

[8] François, C.: International Encyclopedia of Systems and Cybernetics. $2^{\text {nd }}$ edition. K. G. Saur Verlag. Muenchen, 2000

[9] Greaver II M. F.: Strategic Outsourcing: A Structured Approach to Decision and Initiatives, 1999

[10] Gubi, E., Arlbjørn, J.S. and Johansen, J. (2003), “Doctoral dissertations in logistics and supply chain management. A review of Scandinavian contributions from 1990 to 2001", International Journal of Physical Distribution \& Logistics Management, Vol. 33 No. 10, pp. 854-85.

[11] Hrast, A., Mulej, M., Knez-Riedl, J., editors: Družbena odgovornost in izzivi časa 2006. Proceedings. Maribor: IRDO. On CD (printed abstracts - bilingual), 2006

[12] Hrast, A., Mulej, M., Knez-Riedl, J., editors: Družbena odgovornost 2007. Proceedings of the $2^{\text {nd }}$ IRDO Conference on Social responsibility. IRDO Inštitut za razvoj družbene odgovornosti. Maribor. Na CD (printed abstracts, proceedings in Slovenian and English, več prispevkov $v$ angleščini), 2007

[13] Hrast, A., Mulej, M.: Prispevki družbene odgovornosti $k$ dolgoročni uspešnosti vseh udeležencev na trgu: zbornik prispevkov predavateljev. Maribor: IRDO Inštitut za razvoj družbene odgovornosti, 2008. 1 optic disk (CD-ROM), barve. ISBN 978-961-91828-3-3. http://www.irdo.si, 2008

[14] Hrast, A., Mulej, M.: Delo - most za sodelovanje: odnosi do zaposlenih in različnih starostnih generacij: zbornik povzetkov prispevkov $=$ Work - a bridge to cooperation: relations with co-workwrs and different age generations: conference proceedings abstracts. Maribor: IRDO - Inštitut za razvoj družbene odgovornosti, 2009

[15] Huston, L. and N. Sakkab: Connect and Develop. Inside Procter \& Gamble's New Model for Innovation. Harvard Business Review, March: 1-9, 2006

[16] IBM: The Global Innovation Outlook. Armonk, NY: IBM, 2006

[17] Knez M., Cedilnik M., Semolič B.: Logistika in poslovanje logističnih podjetij. Celje: Fakulteta za logistiko UM, 2007

[18] Knez-Riedl, J., Mulej, M. and Zenko, Z.: Approaching sustainable enterprise. In: Lasker, G. E., Hiwaki, K. 
(Eds.): Sustainable development and global community. Baden Baden: International Institute for Advanced Studies in Systems Research and Cybernetics, 2001

[19] New, S.J. and Payne, P. (1995), "Research frameworks in logistics: three models, seven dinners and a survey", International Journal of Physical Distribution \& Logistics Management, Vol. 25 No. 10, pp. 60-77.

[20] Mulej, M.: Ustvarjalno delo in dialektična teorija sistemov. Celje: Razvojni center, 1979

[21] Mulej. M.: Inoviranje navad države in manjših podjetij. Univerza na Primorskem, Fakulteta za management. Koper, 2007

[22] Mulej, M.: Systems theory - a worldview and/or a methodology aimed at requisite holism/realism of humans' thinking, decisions and action. Systems Research and Behavioral Science, 24, 3, 347-357, 2007a

[23] Mulej, M., in soavtorji Hyaeverinen, L., Jurše, K., Rafolt, B., Rebernik, M., Sedevčič, M., Uršič, D. Inovacijski management. I. knjiga Inoviranje managementa. Univerza v Mariboru, Ekonomsko-poslovna fakulteta, Maribor, 1994, reprinted also in 2007

[24] Mulej, M., in soavtorji Fatur, P. Knez-Riedl, J., Kokol, A., Mulej, N., Potočan, V., Prosenak, D., Škafar, B., Ženko, Z.: Invencijsko-inovacijski management $\mathrm{z}$ uporabo dialektične teorije sistemov (podlaga za uresničitev ciljev Evropske unije glede inoviranja). Inštitut za inovacije in tehnologijo Korona plus, d.o.o., Ljubljana, 2008

[25] Mulej, M. Prosenak, D.: Society and Economy of Social Responsibility - The Fifth Phase of Socio-economic Development? In: Hrast, A., Mulej, M., Knez-Riedl, J., eds., 2007

[26] Nussbaum, B., Berner, R., Brady, D.: Special Report. Get Creative! How to Build Innovative Companies. And: A Creative Corporation Toolbox. Business Week, Special Report, 8/15 August: 51-68, 2005
[27] Ogorelec A.: Logistika. Organiziranje in upravljanje logističnih procesov. Maribor: Univerza v Mariboru, Ekonomsko-poslovna fakulteta, 1996

[28] Potočan, V., Mulej, M, editors: Transition into an Innovative Enterprise. University of Maribor, Faculty of Economics and Business, Maribor, 2007

[29] Potočan, V., Mulej, M.: Ethics of a Sustainable Enterprise and the Need for it. Syst. pract. action res., 2007, vol. 20, no. 2, pp. [127]-140, 2007a

[30] Rosi, B.: Prenova omrežnega razmišljanja z aplikacijo na procesih v železniški dejavnosti. University of Maribor, Faculty of Economics and Business, Maribor, 2004

[31] Rosi, B., Mulej, M.: Dialectical network thinking methodology supportive of requisitely holistic creativity. IDIMT-2005, Proceedings. Linz: Universitätsverlag R. Trauner, 2005

[32] Rosi, B., Mulej, M.: The dialectical network thinking - a new systems theory concerned with management. Kybernetes, vol. 35, no. 7/8, 2006

[33] Rosi, B.: Ali ste pripravljeni dialektično omrežno razmišljati? RoBo, s.p., Maribor, 2008

[34] Rozman, R., Kovač, J.: Družbena odgovornost in etika $v$ organizacijah : zbornik referatov. Univerza v Mariboru, Fakulteta za organizacijske vede, Kranj; Zveza organizatorjev Slovenije, Kranj; Univerza v Ljubljani, Ekonomska fakulteta, Ljubljana. Kranj, 2006

[35] Stein, M.: Special Report. The Climate Change, The Economic Argument. Research*eu, No. 52, June, pp. 14-15. Interview with N. Stern, author of 'The Economics of Climate Change', 2006, The Economist Print edition, 2007

[36] Strebel, H., Schwarz, E.: Kreislauforientierte Unternehmenskooperationen. Innovative Verwertungsnetze. Oldenburg Verlag, München, 1998

[37] Bolwijn, T. \& Kumpe, T. Manufacturing in 1990's, Long Range Planning, 23(4), 1990

[38] Wikipedija - prosta enciklopedija. 
